\title{
A SURVEY OF SUB-TROPICAL NURSERY PLANTS FOR FUNGAL DISEASES IN NORTHLAND
}

\author{
M. BRAITHWAITE ${ }^{1}$, C.F. HILL ${ }^{2}$, S. GANEV ${ }^{1}$, J.M. PAY ${ }^{1}$, \\ H.G. PEARSON ${ }^{2}$ and B.J.R. ALEXANDER ${ }^{2}$ \\ ${ }^{1}$ Investigation and Diagnostic Centre, Biosecurity New Zealand, \\ MAF, PO Box 24, Lincoln, New Zealand \\ ${ }^{2}$ Investigation and Diagnostic Centre, Biosecurity New Zealand, \\ MAF, PO Box 2095, Auckland, New Zealand
}

Corresponding author: mark.braithwaite@maf.govt.nz.

\begin{abstract}
During 2003 and 2004 forty-five randomly selected wholesale and retail plant nurseries were surveyed for plant diseases. The plant families Agavaceae, Annonaceae, Arecaceae, Bromeliaceae, Cycadaceae and Musaceae were targeted. Plants were examined in situ for disease symptoms as well as samples being collected for laboratory analyses. Fungi were identified using morphological characteristics, and where necessary with molecular techniques. The survey resulted in a range of fungi being identified from the target plants. These fungi ranged from saprophytes to plant pathogens, some of which may have undesirable effects on New Zealand's biodiversity or economy. Many new host/ pathogen records were observed and several fungi were detected for the first time in New Zealand. This paper presents and discusses the results of these findings.
\end{abstract}

Keywords: subtropical, nursery, survey, new records.

\section{INTRODUCTION}

The Ministry of Agriculture and Forestry (MAF) is committed to ongoing plant health surveillance and has conducted comprehensive crop surveys for pests and diseases over a number of years (Dymock \& Holder 1996; Braithwaite et al. 1998; Ganev et al. 1999). These surveys targeted specific crops and all pests and disease were identified with an emphasis on detecting existing and new recordings for New Zealand.

The primary aim of the present survey was to identify fungal pathogens associated with ornamental plants from designated families of tropical and subtropical origin grown in Northland. Importation of ornamental plants and foliage has increased in significance and little was known of the disease status of these plants in New Zealand. Hence it was important to survey these plants and determine which diseases were present in New Zealand. The data obtained from these surveys are used to prepare pest lists of existing and new fungal/host associations. This information is used for setting import specifications, which assist with decisions made on plants held in post entry quarantine and facilitate ongoing trade in plants and plant products.

\section{MATERIALS AND METHODS}

The species of plants surveyed and the geographical area covered were determined by MAF Biosecurity New Zealand. Surveyed sites in Northland were selected from lists of wholesale and retail plant nurseries provided by the nursery industry.

A total of forty-five randomly selected sites were surveyed by Investigation and Diagnostic Centre staff during 2003 and 2004. The plant families Agavaceae, Annonaceae, Arecaceae, Bromeliaceae, Cycadaceae and Musaceae were targeted. At each site all target species were examined for visual disease symptoms, especially foliage 
pathogens causing leaf spots and stem cankers as well as diseases causing plant collapse. Infected plant parts (leaves, stems or roots) were collected and placed into individually labelled plastic bags and sealed. A total of 245 diseased plant samples were collected over the two year period. The survey was not based on statistical methods but the examination and sampling of observed disease symptoms. Standard hygiene procedures were carried out at each site to prevent the potential spread of plant pathogens between nursery sites. These included disposable overalls and decontamination of all sampling equipment. All samples were given a unique identification number.

The determination of fungi present was made either directly by microscopic examination or indirectly by isolation to agar culture. Plant tissues showing infection were excised and surface sterilised for $1 \mathrm{~min}$ in $1 \%$ sodium hyporchlorite, followed by a 1 min wash in sterile water. Small pieces of tissue from the margin of diseased and healthy tissues were plated directly onto prune extract agar and incubated at $20^{\circ} \mathrm{C} \pm 1^{\circ} \mathrm{C}$ for up to 10 days or until sufficient growth or sporulation enabled identification. Where possible, identifications were carried out to species level. Fusarium spp. were identified to species level using molecular techniques, which involved obtaining sequences of the translation elongation factor gene (O'Donnell et al. 1998) and comparing them to authenticated sequences at the internet-based Fusarium Database (Geiser et al. 2004). Non-sporulating fungi were identified by comparing sequences of their ITS region (using primers ITS1-F and ITS4) and comparing these to sequences deposited at the GenBank database (White et al. 1990; Gardes \& Bruns 1993).

This survey focused on organisms with a primary nature of association, where the organism is able to invade and gain sustenance from intact plant tissues and may cause damage possibility leading to economic loss. Although some saprophytic fungi were identified during this survey, data are not presented here. All new pest associations were entered into MAF's Plant Pest Information Network database (PPIN), which will soon be available on the internet. Any organism new to New Zealand was validated by another practising plant pathologist from New Zealand or overseas. New to New Zealand fungi were investigated further by MAF Biosecurity to determine their distribution and economic impact and whether eradication was feasible.

\section{RESULTS AND DISCUSSION}

Two hundred and forty-five diseased plants were sampled and analysed for plant diseases during the surveys carried out in 2003 and 2004. Eighty-two fungal species were identified representing more than six hundred pest/host associations. Their significance varied from saprophytic fungi with no economic importance through to those that may have undesirable effects on New Zealand biodiversity or affect market access. Significant plant pathogens that affect primary production were also detected.

\section{New to New Zealand records}

Seven fungi, Coniothyrium concentricum, Fusarium phyllophilum, F. sterilihyphosum, Graphium penicillioides and three new Mycosphaerella spp., (P. Crous \& E. Groenewald, pers. comm.) were recorded in New Zealand for the first time (Table 1). Graphium penicillioides was considered a saprophytic species of no economic concern. Coniothyrium concentricum and $F$. phyllophilum were associated with leaf lesions, predominantly on Dracaena and Sansevieria, whereas F. sterilihyphosum was associated with leaf lesions on Bromiliads. These two Fusarium spp. have periodically been identified on imported plant material in post entry quarantine facilities in New Zealand. Knowledge that these fungi are now established in New Zealand has implications in the setting of plant importation standards. MAF Biosecurity New Zealand has now determined that these Fusarium spp. are present and widely distributed throughout the Northland region. The significance of the three Mycosphaerella spp. is uncertain. Direct sequencing of the ITS regions of their ribosomal DNA did not specifically match any sequences on GenBank or at the Centraalbureau voor Schimmelcultures (CBS) databases. Although the isolates do cluster within Mycosphaerella, they are likely to be new or undescribed species. Additional work will be conducted at CBS. Their nature of 
association has not been determined and since they were isolated from potentially dead tissues they may either be endophytic or pathogenic.

TABLE 1: New host recordings for fungi identified for the first time in New Zealand during the 2003 and 2004 surveys.

\begin{tabular}{|c|c|}
\hline Pest organism & Host \\
\hline Coniothyrium concentricum ${ }^{1}$ & $\begin{array}{l}\text { Agave sp., Beaucarnea recurvata, Dracaena sp., } \\
\text { Dracaena draco, Rhopalostylis sp., Sansevieria sp., } \\
\text { Trachycarpus fortunei, Yucca sp. }\end{array}$ \\
\hline Fusarium phyllophilum $^{2}$ & $\begin{array}{l}\text { Dioon spinulosum, Dracaena sp., Dracaena draco, } \\
\text { Sansevieria trifasciata }\end{array}$ \\
\hline Fusarium sterilihyphosum ${ }^{2}$ & $\begin{array}{l}\text { Aechmea luddemanniana, Alcantarea imperialis, } \\
\text { Dyckia sp., Neoregelia sp., Nidularium amazonicum }\end{array}$ \\
\hline Graphium penicillioides $^{1}$ & Annona cherimola \\
\hline Mycosphaerella sp. $A^{3}$ & Bromelia sp., Guzmania sp. \\
\hline Mycosphaerella sp. $B^{3}$ & Vriesea sp. \\
\hline Mycosphaerella sp. $C^{3}$ & $\begin{array}{l}\text { Aechmea fulgens, Chrysalidocarpus lutescens, } \\
\text { Cordyline baueri, Dracaena draco, Guzmania sp. }\end{array}$ \\
\hline
\end{tabular}

${ }^{1}$ Identified by morphological characteristics.

${ }^{2}$ Identified by DNA direct sequencing and morphological characteristics.

${ }^{3}$ Identified by DNA direct sequencing.

\section{New primary and secondary pest/host associations}

Thirty-five fungi determined as primary pathogens and representing new pest/host associations for New Zealand were identified during the 2003 and 2004 surveys (Table 2). In this survey, Glomerella cingulata and Colletotrichum acutatum were the most commonly isolated fungi, usually associated with leaf spots on the various hosts. These fungi are widespread in New Zealand, commonly associated with leaf spots and fruit rots. Eight Fusarium spp. (including the two new to New Zealand species) were also detected during this survey. Fusarium spp. are relatively common in New Zealand on a wide range of hosts where they mostly cause root rots (Braithwaite et al. 1998). Many Fusarium spp. are economic pests. However, in this survey they were most commonly cultured from leaf lesions. The other primary and secondary fungi cultured were mostly minor, leaf-spotting organisms. These fungi commonly occur on a wide range of hosts in New Zealand. This list of pest/host associations provides valuable information on the fungi associated with these hosts in New Zealand.

\section{General Discussion}

The detection of economically important exotic fungi incursions mostly relies on passive sample submission from the public and limited planned surveillance. The identification of seven fungi new to New Zealand from this survey, some of which may have been present but undetected for some time, and the significant number of new host associations emphasised the importance of conducting these types of surveys.

During this survey, many new host records were observed for fungi previously recorded in New Zealand. This commonly occurs during disease surveys of this type (Dymock \& Holder 1996). Little was known about the disease status of these targeted and mostly imported nursery plants. 


\section{TABLE 2: New primary and secondary pest/host associations recorded during the 2003 and 2004 surveys.}

\begin{tabular}{|c|c|}
\hline Pest organism & Host \\
\hline Botryosphaeria dothidea & Annona cheromila \\
\hline Botryosphaeria parva & $\begin{array}{l}\text { Agave attenvata, Phormium sp., Sansevieria sp., } \\
\text { Solanum muricatum }\end{array}$ \\
\hline Botyrtis cinerea & $\begin{array}{l}\text { Aechmea luddemanniana, Chamaedorea elegans, Dracaena } \mathrm{sp} ., \\
\text { Musa } \text { sp.,Neoregelia } \text { sp., Psidium guajava, Strelitzia reginae, Vriesea } \\
\text { platynema, Yucca elephantipes }\end{array}$ \\
\hline Calonectria pauciramosa & Callistemon viminalis \\
\hline Cercospora apii & Archontophoenix sp. \\
\hline Cochliobolus cynodontis & Dypsis baronii, Syagrus romanzoffiana \\
\hline Colletotrichum acutatum & $\begin{array}{l}\text { Annona cherimola, Archontophoenix sp., Butia capitata, Chamaedorea } \\
\text { elegans, Chrysalidocarpus lutescens, Doryanthes palmeri, Jubaea } \\
\text { chilensis, Musa sp., Psidium guajava, Solanum muricatum }\end{array}$ \\
\hline Colletotrichum capsici & Bromelia sp., Yисca sp. \\
\hline Colletotrichum crassipes & Vriesea sp. \\
\hline Curvularia lunata & Chrysalidocarpus lutescens \\
\hline Fusarium anthophilum & Chrysalidocarpus lutescens \\
\hline Fusarium compactum & Agave attenuata \\
\hline Fusarium oxysporum & $\begin{array}{l}\text { Beaucarnea recurvata, Cordyline baueri, Dracaena draco, } \\
\text { Phormium sp., Sansevieria sp. }\end{array}$ \\
\hline Fusarium sambucinum & Musa sp., Rhopalostylis cheesemanii \\
\hline Fusarium sporotrichioides & Archontophoenix sp., Musa sp., Strelitzia reginae, Yucca sp. \\
\hline Fusarium tricinctum & Agave attenuata \\
\hline Fusicoccum luteum & Clivia miniota \\
\hline Gibberella acuminata & Cycas sp., Musa sp., Yucca elephantipes \\
\hline Gibberella baccata & Cycas sp., Musa sp., Yucca elephantipes \\
\hline Gibberella intricans & Beaucarnea recurvata, Musa sp. \\
\hline Gibberella zeae & $\begin{array}{l}\text { Brahea sp., Chamaerops humilis, Musa acuminate, } \\
\text { Olea europaea, Phoenix canariensis, Rhopalostylis cheesemanii, Yucca } \\
\text { elephantipes, Yucca filamentosa }\end{array}$ \\
\hline Glomerella cingulata & $\begin{array}{l}\text { Agave sp., Aloe sp., Archontophoenix alexandrae, Archontophoenix sp., } \\
\text { Brahea armata, Bromelia sp., Cordyline australis, Cycas kennedyana, } \\
\text { Cycas revolute, Dioon spinulosum, Dracaena draco, Dracaena } \\
\text { hookeriana, Dypsis baronii, Howea forsteriana, Jubaea chilensis, } \\
\text { Livistona decipiens, Meryta sinclairii, Musa acuminate, Neodypsis } \\
\text { decaryi, Neoregelia sp., Nidularium innocentii, Phoenix canariensis, } \\
\text { Phoenix roebelinii, Phormium tenax, Psidium cattleianum, Psidium } \\
\text { guajava, Ravenea rivularis, Rhopalostylis baueri, Solanum muricatum, } \\
\text { Washingtonia robusta, Yucca elephantipes, Yucca filamentosa }\end{array}$ \\
\hline Microsphaeropsis olivacea & Dracaena hookeriana, Psidium guajava \\
\hline Nectria haematococca & Dracaena sp. \\
\hline Pestalotiopsis versicolor & $\begin{array}{l}\text { Archontophoenix cunninghamiana, Bromelia } \mathrm{sp} ., \text { Caryota } \mathrm{sp} ., \\
\text { Cycas sp., Dracaena draco, Dyckia } \mathrm{sp} ., \text { Hyophorbe verschaffeltii, } \\
\text { Lepidozamia peroffskyana, Musa } \mathrm{sp} ., \text { Olea europaea, Phoenix } \\
\text { canariensis, Phoenix roebelinii, Rhapis excelsa, Rhopalostylis } \\
\text { cheesemanii, Rhopalostylis sapida, Roystonea sp., Strelitzia nicolai, } \\
\text { Syagrus romanzoffiana, Washingtonia robusta }\end{array}$ \\
\hline Phoma exigua & Annona cherimola, Monstera sp., Solanum muricatum \\
\hline Phoma glomerata & $\begin{array}{l}\text { Archontophoenix cunninghamiana, Guzmania sp., } \\
\text { Ravenea rivularis, Vriesea hieroglyphica, Yucca sp. }\end{array}$ \\
\hline Phoma macrostoma & $\begin{array}{l}\text { Archontophoenix cunninghamiana, Musa x paradisiaca, } \\
\text { Solanum muricatum }\end{array}$ \\
\hline Phoma nigricans & Strelitzia sp. \\
\hline Phoma plurivora & Yucca sp. \\
\hline Phoma pomorum & Astelia sp. \\
\hline Phyllosticta sp. & Roystonea sp. \\
\hline Pseudocercospora sp. & Rhopalostylis cheesemanii, Rhopalostylis sapida \\
\hline Thanatephorus cucumeris & Strelitzia nicolai \\
\hline
\end{tabular}


These lists of pest/host associations did highlight the most common fungi on these surveyed hosts in New Zealand. This information will be useful for the preparation of pest lists used in setting import specifications and providing up to date pest lists for exporters. It is also a valuable resource in setting priorities in disease management and related research in ornamental horticulture.

\section{ACKNOWLEDGEMENTS}

We wish to thank the Investigation and Diagnostic Centre staff for the contributions to different aspects of this survey, the New Zealand Nursery and Garden Industry Association, industry personnel, individual growers for allowing their crops to be sampled, Dr K O'Donnell, Dr Pedro Crous and Dr Ewald Groenewald for culture validation.

\section{REFERENCES}

Braithwaite M, Alexander BJR, Adams RLM 1998. Nationwide survey of pests and diseases of cereal and grass seed crops in New Zealand. Proceedings of the 51st New Zealand Plant Protection Conference: 51-59.

Ganev S, Braithwaite M, Alexander BJR 1999. Nationwide survey of fungal and bacterial diseases of stone fruit crops in New Zealand. 12th Biennial Australasian Plant Pathology Society Conference. p. 66.

Dymock JJ, Holder PW 1996. Nationwide survey of arthropod and molluscan pests on the cut flowers in New Zealand. New Zealand Journal of Crop and Horticultural Science 24: 249-257.

Gardes M, Bruns TD 1993. ITS primers with enhanced specificity for basidiomycetes - application to the identification of mycorrhizae and rusts. Molecular Ecology 2: 113-118.

Geiser DV, del mar Jimenez-gasco M, Kang S, Makalowska I, Veeraraghavan N, Ward TJ, Zhang N, Kuldau GA, O'Donnell K 2004. FUSARIUM-ID v.1.0: A DNA sequence database for identifying Fusarium. The European Journal of Plant Pathology 110:473-479.

O’Donnell K, Kistler HC, Cigelnik E, Ploetz RC 1998. Multiple evolutionary origins of the fungus causing Panama disease of banana: Concordant evidence from nuclear and mitochondrial gene genealogies. Proceedings of the National Academy of Science USA 95: 2044-2049.

White TJ, Bruns T, Lee S, Taylor J 1990. Amplifiation and direct sequencing of fungal ribosomal RNA genes for phylogenetics. In: Innis MA, Gelfand DH, Sninsky JJ, White TJ ed. Methods in plant molecular biology and biotechnology. Academic Press, San Diego. Pp. 315-332. 